\title{
Trademark.COM: Trademark LAW IN Cyberspace
}

\author{
LISA KATZ JONES
}

This article examines the current issues in trademark law surrounding internet domain names. The author introduces the topic with a detailed explanation of the use and purpose of domain names, the significance of the various levels in domain names and how domain names compare and contract with IP addresses. Of significant difference is the use of words and names in domain names. Organizations often use recognizable and familiar names to improve the chance Internet users will access their websites. Trademark issues are sparked by the battle to obtain and/or retain these highly sought after domain names. The author discusses the areas of conflict when: I) a domain name is registered by an individual who has no connection with the mark, 2) two or more organizations have claims to the same domain name, 3) one domain name is confusingly similar to another, and 4) when second level domain names can be assigned to multiple first level domain names. Two essential legal issues are identified: whether domain names are protectable as trademarks and whether a domain name can violate a trademark. Courts have used the analogy of telephone mnemonics to help answer these issues in favour of recognizing mnemonics as a protectable trademark, although there is split authority on how much protection can be given to domain names that incorporate generic terms. Trends in litigation in the United States, Canada, and the United Kingdom are discussed. Despite the de facto judicial power given to NSI for dispute resolution, the author identifies fundamental flaws of the NSI policy owing the current controversies over Internet domain names. The article concludes with a discussion of several major proposals to implement changes regarding domain names allocation.
L'auteure examine les questions d'actualité touchant les droits de propriété industrielle et commerciale régissant les noms de domaine Internet. Elle commence par expliquer en détail la fonction des noms de domaine, leur construction hiérarchique, et ce qui les distingue des numéros IP - la différence notable étant l'utilisation de mots et de noms. Les organismes utilisent souvent des noms connus ou evocateurs pour attirer les internautes vers leur site. L'obtention ou la protection des noms de domaine très convoités soulèvent des questions de propriété industrielle et commerciale. L'auteure traitent des conflits possibles quand I) un nom de domaine est enregistré ou déposé par une personne sans lien avec la marque de commerce, 2) plusieurs organismes réclament le mème nom de domaine. 3) un nom prête à confusion avec un nom de domaine déjà enregistré; et 4) des noms de domaine de second niveau sont octroyés $\dot{a}$ de multiples domaines de premier niveau. Deux questions fondamentales se posent : peut-on protéger les noms de domaine au même titre que les marques de commerce; et un nom de domaine est-il susceptible de violer la Loi sur les marques de commerce? Évoquant l'analogie des numéros de téléphone mnémoniques, les tribunaux semblent enclins à reconnaitre que les caractéristiques mnémoniques d'un nom peuvent lui conférer un caractère distinct susceptible de bénéficier de la protection légale (bien que le degré de protection à conférer aux noms de domaine comportant des termes génériques ne fasse pas ('unanimité). L'auteure fait l'état des tendances aux États-Unis, au Canada et en GrandeBretagne à cet égard. Malgré le pouvoir judiciaire de fait exercé par I'INS en matière de résolution de conflits, l'auteure note des lacunes notables $\dot{a}$ en juger par les controverses que suscitent les noms de domaine. En conclusion, elle propose des modifications quant à l'atribution des noms de domaine.

\section{TABLE OF CONTENTS}

I. INTRODUCTION . . . . . . . . . . . . . . . . . . . . . . . . . . 992

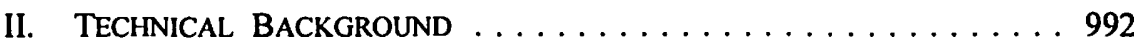

A. DOMAIN NAMES . . . . . . . . . . . . . . . 993

B. THE WORLD WIDE WEB . . . . . . . . . . . . . . 996 
III. THE CONFLICTS $\ldots \ldots \ldots \ldots \ldots \ldots \ldots \ldots \ldots \ldots \ldots \ldots$

A. CYBer-SQuatting $\ldots \ldots \ldots \ldots \ldots \ldots \ldots \ldots \ldots \ldots 9 . \ldots \ldots$

B. CONCURRENT USE $\ldots \ldots \ldots \ldots \ldots \ldots \ldots \ldots \ldots . \ldots 99$

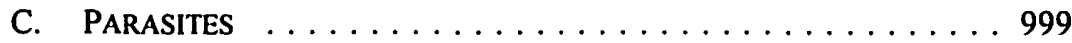

D. XYZ.COM v. XYZ.ORG $\ldots \ldots \ldots \ldots \ldots \ldots \ldots \ldots 1000$

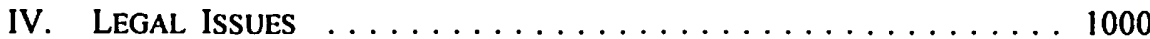

A. AnAlogies $\ldots \ldots \ldots \ldots \ldots \ldots \ldots \ldots \ldots \ldots \ldots$

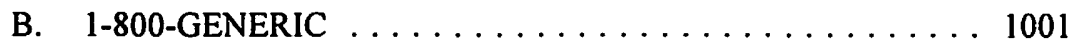

V. NSI DOMaIN NAME DisPute POLICY $\ldots \ldots \ldots \ldots \ldots \ldots \ldots 1003$

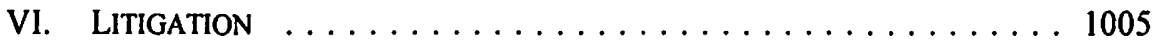

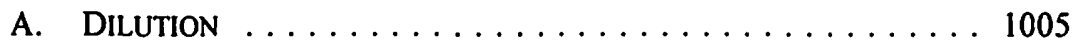

B. Canadian litigation ................. 1007

C. U.K. Litigation . . . . . . . . . . . . . . . . . . 1009

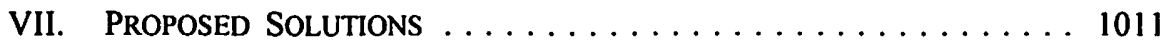

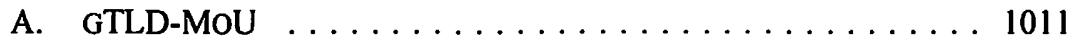

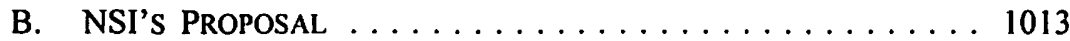

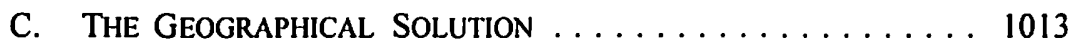

D. Classification of GOOdS AND SERvices ......... 1015

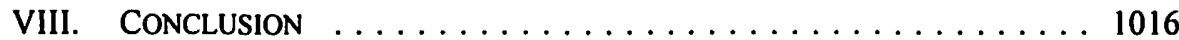

\section{INTRODUCTION}

As interpreters of symbols, humans are far more sophisticated than computers: we can tolerate high degrees of ambiguity, context-sensitivity, and vagueness. For instance, we readily pick up on contexts in which the symbol "cc" means "carbon-copy," although in a different context it might mean "cubic-centimetre." Trademark law reflects our abilities to interpret symbols contextually in that it tolerates one mark being used in multiple and distinct contexts.

Computers, on the other hand, require symbols with unambiguous interpretations. Internet domain names, as a computer addressing language, must be unique and context-insensitive. Domain names are unique and global; trademarks are multiple and local. Herein lies the difficulty for trademark law on the Internet: while the Internet transcends borders, traditional trademark protection extends only to marks that have an identifiable locus.

Court dockets in the U.S. and abroad have been filled with such issues as "cybersquatting" and domain-name grabbing. While many of the issues and problems that arise may be analyzed and resolved with traditional notions of trademark law, others require an investigation into the effects of cyberspace on the commercial marketplace. This article will examine Canadian, American, and British caselaw to determine how the courts from each jurisdiction have adapted trademark law to cyberspace.

\section{TeChNiCAl BACKground}

The Internet is a worldwide network of millions of computers. Each computer on the network has a unique address used for purposes of routing information around the 
network. There are two ways of describing the location or address of a particular computer on the Internet. The first is by its IP address which is something akin to a telephone number on the Internet. An IP address consists of a string of numbers separated by periods or dots. One such IP address might be the string "209.135.2.16." IP addresses have a hierarchical, branching structure with the numbers read left to right corresponding to smaller subdivisions of the network: the numbers in the series refer to sets of computers with the sets decreasing in size with each number; the last number refers to an individual computer or host. Two host computers may be located on the same sub-network and so will have in common the first numbers of their IP addresses, but they must differ on the last number. The Internet Assigned Numbers Authority (IANA) is responsible for allocating IP numbers.

Computers on the Internet relay data across the network according to IP addresses. However, like phone numbers, IP numbers are difficult for human operators to remember and use. To make the Internet easier for its users, there is a separate addressing convention, in parallel with the IP numbers. This parallel addressing convention is known as the Domain Name System (DNS). Under the DNS, host computers on the network may be given a mnemonic designation or alias, called a domain name. The two addressing conventions exist in parallel by virtue of the fact that each domain name is paired with its equivalent IP address. Apart from these pairings, there is no logical or straightforward connection between IP addresses and domain names.' The pairings are kept in large databases, or lookup tables, on dedicated Internet computers called name servers. The DNS consults these lookup tables to translate automatically the "user-friendly" mnemonic domain names into numerical IP addresses, the language by which Internet functions actually take place. IP addressing is therefore the more fundamental of the two addressing conventions; IP addresses are the "real" Internet addresses. The DNS is merely an overlay for the purposes of improving the useability of the Internet.

\section{A. Domain Names}

Domain names are alpha-numeric strings delimited by dots in the same manner as IP numbers. ${ }^{2}$ Like IP numbers, domain names have a hierarchical structure though in an increasing, as opposed to decreasing, order of size from left to right. For instance, the domain "toad" is a subdomain of the domain "toadhall" in the fictitious example "toad.toadhall." As with IP addresses, the element in a domain name with the smallest scope picks out an individual host computer. Since every domain name is paired with one and only one IP address, and since IP addresses uniquely pick out a host computer on the network, domain names are also unique. No two organizations or entities may use the same domain name, though elements of domain names may be shared. For

For instance, there is no isomorphism between the two systems. That is to say, there is no one-toone correspondence between elements in an IP address and elements in the equivalent domain name.

$2 \quad$ Allowed characters in a domain name are the letters "a" through " $z$," the numerals " 0 " through "9," and the hyphen. No other punctuation is allowed, nor are spaces; case does not matter. Without capitalization, stylization, or any of the other design features commonly used to distinguish one trademark from another, domain names are a very arid environment for trademarks. 
instance, it is possible to have "toad.wind.willows," "badger.wind.willows," and "toad.toadhall" all existing simultaneously on the network. The only rule is that each domain name, taken in its entirety, must be unique.

The right-most element in a domain name is known as the top-level domain, or TLD. In all but a few noteworthy cases, the TLD is a two-letter abbreviation of the name of a country or territory: "fr" for France, "hk" for Hong Kong, and so on. The exceptions to the geographical TLDs are a half-dozen "generic" top-level domains, or gTLDs. The generic top-level domain "com," signifying commercial activity, is by far the most prevalent. ${ }^{3}$ Other gTLDs include "edu," for educational institutions, "org," for nonprofit organizations, and "net" for network infrastructure. The gTLDs are commonly mistaken for substitutes for a U.S.-only, geographical TLD. U.S. organizations have historically been the overwhelming majority of users in the generic top-level domains. This is probably owing to the fact that the Internet began as a U.S. phenomenon with its roots in a U.S. Department of Defence communications project. ${ }^{4}$ There does exist a "us" geographical TLD for the United States, but it is rarely used. Instead, U.S.-based organizations typically seek to use gTLDs as the root domain for their Internet addresses. As a result, there is a strong presumption that a domain name in the "com" TLD is being used by a company in the U.S. However, many organizations around the world use domain names under the generic hierarchies, ignoring the geographical TLDs for their own countries.

The second-to-last element in a domain name is known as the Second Level Domain, or SLD. Where the TLD is geographical, the SLD name may describe a particular geopolitical sub-region of the country of the TLD: the SLD " $q c$ " stands for Quebec when appearing within the "ca" TLD;" "il" within the "us" geographical TLD stands for Illinois. Geographical SLD names are relatively rare, however. In some countries, such as in certain Commonwealth nations, the structure of the SLD hierarchy duplicates that of the gTLDs. In Australia (TLD "au"), for instance, the SLDs are "com," "edu," "gov," and so on. ${ }^{6}$ These exceptional cases aside, the SLD name typically represents a specific organization by either being a version of the name of the organization, or its acronym. For instance, "princeton.edu" are the second and top-level domains of the domain name for Princeton University, as is "epa.gov" for the U.S. Environmental Protection Agency. SLD names may be up to a maximum of twenty-four characters long.

3 According to figures cited in 1. Nathenson, "Showdown at the Domain Name Corral: Property Rights and Personal Jurisdiction Over Squatters, Poachers and Other Parasites" (1997) 58 U. Pitt. L. Rev. 911, the "com" hierarchy outstrips the other gTLDs in size by a factor of nine to one.

4 The gTLDs "gov" and "mil" are the exclusive domain of the U.S. government and military, respectively.

5 The SLD in the "ca" TLD is not limited to provincial abbreviations. The "gc" SLD, for instance, stands for "Government of Canada." Corporate acronyms and monikers are quite common in the "ca" heirarchy.

"In the U.K. (TLD "uk"), the SLDs are "ac" for academic, "co" for commercial, and "gov" for governmental, among others. Though the abbreviations are different, their functions are the same as the gTLDs. Israel also follows this pattern. 
To create a SLD name under a TLD, one must apply to the registration authority for that TLD. ${ }^{7}$ Each country has a domain name registrar for its geographical TLD. In Canada, the registration authority consists of a committee of members of CA Net, the Canadian Internet authority. The gTLDs form a special class with one registrar for all domains. The registrar for the gTLDs is known as the Internet Information Center, or InterNIC, and is operated in the United States by Network Solutions Inc. ("NSI") under contract from the National Science Foundation (NSF). To have an SLD name registered in a TLD amounts in essence to having an IP number assigned to the newly created domain name and having that name/number pairing entered into the DNS name servers for that TLD. Additional sub-domains under an SLD may be created by the holder of the SLD without the need to register those sub-domain names with the TLD registration authority. ${ }^{8}$ For instance, the Very Small State University may create for itself "studentsunion.vsmsu.edu."

Domain names are in some respects similar to postal addresses. ${ }^{9}$ Take for example the domain name "admin.humberc.on.ca." The leftmost element denotes the smallest level - the individual computer; in this case, a computer named "admin." Successive elements stand for increasingly larger branches of the DNS hierarchy. The next element in the example denotes a particular organization, Humber College. The last two elements in the example pick out geo-political entities: "on" denotes Ontario; "ca" denotes Canada. The entire domain name in our example can be read as "Administration, Humber College, Ontario, Canada." Read this way, the domain name bears a striking resemblance to the postal address of the institution with approximately the same hierarchically embedded structure. In keeping with their similarities with postal addresses, domain names form the bases for e-mail addresses. In an e-mail address, a prefix representing a particular individual is conjoined to the domain name by the “@” sign: e.g., "majones@admin.humberc.on.ca."

TLDs and SLDs can also be compared to telephone country codes and area codes. ${ }^{10}$ Just as there can only be one occurrence of a telephone number within any one area code, there can be only one occurrence of a particular name subsumed under a higherlevel domain. On the other hand, the number 987-1234 can occur in both the 604 and 902 area codes. Similarly, it is possible to have both "xyz.bc.ca" and "xyz.ns.ca" as

This would apply mutatis mutandis for creating third-level domain names in countries where the SLD structure matches that of the gTLDs. See supra note 6 and related text.

The domain name must, however, be entered into the DNS name server for the sub-network, so that traffic to that domain name may be resolved into the correct IP number.

In the vernacular of the Internet, regular postal mail is known as "snail mail" - a disparaging remark on the comparatively sluggish speed of delivering mail through physical, as opposed to virtual, means.

As noted above, IP addresses are more closely analogous to telephone numbers. However, IP numbers do not have the equivalent of country and area codes. Though domain names are partially organized according to countries, and in some cases regions, there is no one-to-one correspondence between IP numbers and domain names. This entails that there is no element within an IP address that necessarily picks out a certain country or region. 
Internet domain names. Like the toll-free area codes " 800 " and " 888 ," the gTLDs carry with them no implications for geographical location. ${ }^{.1}$

Two developments in the history of the Internet have brought about the current trademark controversy over domain names. The first crucial development was the opening up in 1991 of the Internet to commercial use, overturning the policy that commercial traffic was not considered an acceptable use of the publicly-funded information infrastructure. There were domain names under the "com" hierarchy prior to the 1990s, but these were rare and typically belonged to companies with a strong emphasis on research, especially in the field of computing. For instance, "parc.xerox.com" stood for Palo Alto Research Center, Xerox Corporation; "watson.ibm.com" stood for Watson Research Center, IBM Corporation. The third-level domains maintained the parallelism between domain names and postal addresses. Indeed, the InterNIC encouraged the use of third-level domains:

Our basic policy at the InterNIC is to register one domain per "organization." We would prefer that divisions, subsidiaries, etc. be handled as 3 rd level domains. ... The existence of a registered trademark is not sufficient reason for registering it as a domain name. ... Trademarks should be treated as thirdlevel domains. ${ }^{12}$

The policy was unclear as to what constitutes "one organization." The policy was not rigorously enforced. By October 1994, 670 companies had registered more than one domain name. ${ }^{13}$ The policy appears to have been dropped. ${ }^{14}$ The restriction on trademarks has also been dropped, for it is now quite common for the SLD to incorporate a trademark. For example, one may find "sperrytopsider.com." With names of products now commonly appearing in the SLD, as opposed to the third or lower level, many domain names have lost their earlier intuitive structure that they shared with postal addresses.

\section{B. THE WORLD WIDE WEB}

Though some companies were slow to appreciate the commercial value of the Internet, a second development hurried the Oklahoma land rush for domain names. Since its appearance in 1992, the World Wide Web (WWW, or simply, "the Web") has become the dominant use of the Internet. ${ }^{15}$ The Web has changed the Internet from

"With telephone numbers, there is the possibility of adding a mnemonic layer by means of the convention that maps; for example, HELP to 4356. Trademark litigation over the use of telephone mnemonics forms an important basis from which to extend the law to domain name disputes. See below.

12 G.W. Hamilton, "Trademarks on the Internet: Confusion, Collusion, or Dilution?" (1995) 4 Tex. Intell. Prop. L.J. 1 at 4.

13 K.S. Dueker, "Trademark Law Lost in Cyberspace: Trademark Protection For Internet Addresses" (1996) 9 Harv. J.L. \& Tech. 483 at 500.

14 No mention of such a policy can be found at present on the InterNIC web site http: //www.internic.net.

is In the vernacular of the computer industry, the Web is the "killer app" ('application') of the Internet - the one use that is responsible for its explosive growth and unparalleled importance. 
the arcane doyen of an elite of academics and researchers to a mass consumer culture phenomenon. Through this medium, many thousands of companies have set up virtual storefronts on the Internet to disseminate marketing literature, publish stockholder information, provide customer service, and even to sell products and services online. Companies find it valuable to have domain names as the basis for their online presence that are close mnemonic approximations of their company name or trademark. The reason for this preference has to do with the fact that consumers use the Web as a research tool, actively seeking out information on companies and products. A company would therefore want to ensure that their information is easily located.

The computer files that make up a Web document, known as a web "page," are stored on Internet hosts called web servers. The domain names of web servers typically start with the host name "www"; the higher-level domains, on the other hand, may be anything. At the request of an Internet user, these servers transmit the files across the network to the user's computer. For such a transmission to take place, the user's computer, known as the client, must be instructed on the exact location of the file on the server in order to send a request for that file. ${ }^{16}$ The client may obtain the address of a particular web page in one of two ways, either with or without the user's knowledge of that address. First, the client may pick up the address from instructions contained on another web page; this is known as a "link." A user may jump from one web page to another, via a link, without being aware of the address of the destination page. Second, the user may actively instruct the client to retrieve files from a particular server, by typing the address into the client. It is this latter method that demonstrates the value of a strongly mnemonic domain name.

Users may become aware of a web page address through print, radio, or television advertising, by reading it on company letterhead, or through word of mouth. Having a domain name that can be easily recollected aids the transfer of the web address from wherever it was that the user came across the address, to the computer keyboard. A mnemonic domain name is therefore an asset to a company because it increases traffic to the web page, and also because it helps bridge marketing efforts in traditional media to the online environment.

One need not have previously learned or come across the address to access a particular web page. It is quite common simply to take an educated guess at the correct address. If I were wondering whether the Whosit Corporation has joined the ranks of companies on the Web, the first web address I might try would be "www.whosit.com." The more companies secure guessable domain names, the more reliable guessing concatenation of the domain name of the server, the name of the directory or sub-directory on the server that contains the file, and the filename. There is also a prefix "http:/r" standing for "Hyper Text Transfer Protocol," and the suffix ".html" means "Hyper Text Markup Language." A full URL would look like: "http:/hostname.subdomain.2nd-domain.top-domain/directory/ filename.html." Each document on the Internet has a unique URL. For simplicity's sake, this article will consider URLs to consist only of domain names. This is not an unrealistic assumption, since web servers are often configured such that if the address requested is truncated after the domain name, the server returns a particular default document. 
becomes as a method of finding web pages. With educated guesses being relied upon so frequently as a means of finding web pages, the demand for domain names closely resembling company names and trademarks increases.

Consumer behaviour, together with the perception that customized domain names make the best marketing sense, has created a corporate online culture that is a fertile environment for trademark disputes. The disputes occur primarily over SLDs in the "com" TLD. Most companies consider the "com" domain to be the most appropriate domain for them and so eschew TLDs with geographical connotations. There is the further perception that within the "com" domain, there are not enough names to go around. ${ }^{17}$ The situation is as if everyone wanted a 1-800 telephone number: conflicts were bound to occur.

\section{THE CONFLiCTS}

There are four distinct fact scenarios over which trademark conflicts may arise. First, a trademark could be incorporated into a domain name registered by an individual that has no previous connection with the mark. The second problem occurs when two or more organizations have colourable claims to the same domain name. Third, a trademark issue may arise when one domain name is confusingly similar to another. Lastly, the same second-level domain name can be assigned to multiple first-level domain names. ${ }^{18}$

\section{A. Cyber-Squatting}

Those who intentionally register domain names containing the trademarks of prominent companies in the hopes of demanding ransoms from those companies for the use of the domain name are known as "cyber-squatters." Perhaps the most notorious of cyber-squatters is Dennis Toeppen, who registered hundreds of famous names, and demanded a large fee before transferring the domain name to companies with legitimate claims to the domain names. Among Toeppen's acquisitions were such domain names as: "aircanada.com," "britishairways.com," "deltaairlines.com," "eddiebauer.com," "neiman-marcus.com," "ramadainn.com," and "yankee-stadium.com."' Something akin to squatting occurred when KCRA-TV in Sacramento, California, registered call letters of three of its competitors, "kvie.com," kpwb.com," and "ktxl.com," to deny these competitors their most obvious domain name mnemonic. ${ }^{20}$ Other cases of

17 U.S. Commissioner of Patents and Trademarks, Bruce Lehman, so testified in front of the U.S. House Subcommittee on Courts and Intellectual Property. Reported in The Bureau of National Affairs, Patent, Trademark \& Copyright Journal News (13 November 1997) 55 PTCJ 35, online: Westlaw. Of course, this perception is erroneous: there are literally billions of possible domain names.

There is perhaps a fifth possible situation, in which a third-level of one organization's domain name conflicts with a trademark incorporated into the second-level of that trademark owner's domain name. I know of no cases in which this situation arises.

19 Intermatic v. Toeppen, 40 U.S.P.Q.2d (BNA) 1412 at 1414 (N.D. Ill. 1996).

20 J. Agmon et al, "What's In a Name? - Domain Name Disputes" online: <http://www. paemen.com/lc/internic/domain l.html>. 
domain name grabbing involve companies' gobbling up terms and phrases that are even remotely relevant to their business. For instance, Procter and Gamble laid claim to such desirable domains as "diarrhea.com" and "pimples.com." ${ }^{21}$ Proctor and Gamble probably had no intention to use such domains as their corporate Internet address; rather, their motivation was to deny other companies the cachet of such catchy phrases. $^{22}$

\section{B. Concurrent USE}

Perhaps the most vexing problem for trademark law on the Internet is the issue of concurrent use. Consider the case of Fry's Electronics Inc., a San Francisco computer retailer. Fry's had wanted to use "frys.com" which seemed to be its most obvious choice for a mnemonic, guessable domain name. Fry's wishes were frustrated when it discovered that someone had beaten them to the name. Frenchy Frys, a Seattle distributor of french fry vending machines, had registered and was using the domain name. Fry's Electronics brought suit against Frenchy Frys over the use of the Internet address. $^{23}$ In its complaint, Fry's Electronics cited unfair competition under U.S. trademark law and wire fraud among its causes of action. ${ }^{24}$ Both corporations use a variant of "Fry's" to identify their goods and services in totally different lines of business. It would seem that under traditional trademark law, Fry's Electronics ought to have as much right to use the Internet address "frys.com" as Frenchy Frys. Yet only one may use "frys.com," since domain names on the Internet must be unique. ${ }^{25}$

When a company finds itself in the position of Fry's Electronics, it often tries to wrest the domain away from its holder, even though the holder may have been using the name legitimately for some time. This is known as "reverse domain name hijacking" and is in some ways the converse of squatting. There are two, often complementary, tactics in a reverse domain name grab: initiating the NSI's standing Domain Name Dispute Policy and litigation. This article will discuss NSI's Dispute Policy and concomitant litigation in Sections V and VI, below.

\section{Parasites}

Parasitic domain names are variants on famous domain names. The variation may be a matter of a misspelling, a phonetic equivalence, the substitution of one alpha-numeric character for another, or the insertion of extra characters. A competitor of Teubner and Associates registered "tuebner.com," a common misspelling of the name. Lockheed Martin Corporation sued NSI over the registration of "skunkwrks.com," and

$21 \quad$ "Flux" (November 1995) Wired at 49 online: wired <www.wired.com>.

22 One can register a domain name without having to use it, i.e., without having it resolve to a particular server.

23 Fry's Electronics v. Octave Systems (filed 12 July 1995), California No. 95cv2525 (N.D. Cal.). Filed 12 July 1995).

24 G.A. Barger, "Cybermarks: A Proposed Hierarchial Modeling System of Registration and Internet Architecture for Domain Names" (1996) 29 J. Marshall L. Rev. 623 at 633, n. 53.

25 A similar fact situation is the recent case in which Juno Electric, a maker of light fixtures, took steps to deprive Juno Online, an e-mail service provider, of the domain name "juno.com." 
"skunkwerks.com." The company Zero Micro Software registered "micros0ft.com," substituting the numeral zero for the letter "0." Interlaw had a dispute with The 'Lectric Law Library over the latter's use of "inter-law.com."26

\section{XYZ.COM V. XYZ.ORG}

Most disputes involve two companies' vying for a given SLD in the "com" TLD, where only one may use the domain name because of the network's uniqueness requirement. However, this requirement is not violated if the same SLD string appears in two different TLDs. It is becoming increasingly common for SLD names, particularly acronyms of organizations, to appear in more than one gTLD. While one can typically guess the SLD acronym on the basis of the name of the organization, which TLD to try is often less than certain. ${ }^{27}$ This can result in some humorous, unintended page accesses on the part of the user: one may be trying to reach the International Foodservers and Hoteliers Organization web page but arrive at the Indiana Funeral Home Operators page instead. For the most part, these mistakes are innocuous. However, some cases rely upon the user's ignorance of the correct TLD suffix. For example, if I wanted to visit the American White House web site and were to try "www.whitehouse.com," I would arrive at a web site peddling pornography, its pages replete with silicone-enhanced females. To visit the Clinton residence, on the other hand, I must type "www.whitehouse.org."

\section{LEGAL ISSUES}

Given the fact that trademarks are one-many, while the Internet may only have unique addresses, the potential for trademark conflict is high. The Internet has been compared to the lawless Wild West with grubstakers, con artists, and speculators trying to stake their claim and make a fast fortune. At the same time, the corporate world struggles to cultivate the Internet as a respectable medium of commerce. As businesses awake to the potential of the Internet, there is an increased likelihood of clashes over valuable virtual real estate. To increase confidence in this new way of doing business and provide a level of legal predictability, there must be an articulation of how the basic principles of trademark law apply to the online world. There are essentially two issues to be determined: whether domain names are protectable as trademarks, and whether a domain name can violate a trademark.

\section{A. Analogies}

Appealing to certain analogies helps extend trademark law to the novel area of domain names. The analogy between domain names and telephone mnemonics is

27 One tries to pick up clues from one's knowledge of the nature of the organization: a not-for-profit organization typically points to "org" as the best guess. But this is not infallible. 
perhaps the strongest. The analogy was made in one of the earliest cases involving domain names, MTV Networks v. Curry. ${ }^{28}$ In its decision, the court wrote:

Internet domain names are similar to telephone number mnemonics, but they are of greater importance, since there is no satisfactory Internet equivalent to a telephone company white pages or directory assistance, and domain names can often be guessed. ${ }^{29}$

Telephone mnemonics are similar to domain names in that they also act as a link from the consumer to the product or service being sold. Both telephone mnemonics and domain names correspond to an underlying number, though in the latter case the connection is less direct. Both serve as ways of remembering hard to remember numbers, and both serve as means of contacting a source of goods and services. Like domain names, phone numbers are registered on a first-come, first-served basis. By not having a comprehensive directory, domains become an even more important identifier, owing to their guessability. By contrast, no one would try to guess a telephone mnemonic "CALL - XYZ" in hopes that it would connect to XYZ Inc. Courts have found telephone mnemonics to act as examples of goodwill and have readily applied the law regarding the likelihood of confusion to such marks. ${ }^{30}$ Even phone numbers themselves, without any mnemonic overlay, may be protectable as a trademark. ${ }^{31}$ In Murrin v. Midco, ${ }^{32}$ the court held that allocating $1-800$ numbers on a first-come, firstserved basis was an appropriate method for assigning the numbers.

\section{B. 1-800-GENERIC}

The one complicating factor that stands in the way of trademark protection for all telephone mnemonics, and hence complicates any easy analogy between telephone menonics and domain names, is the use of generic terms. The issue is of utmost importance to domain names. If a company were to register a domain name corresponding to a generic term, it would have a de facto monopoly on that term over the entire Internet. The cachet of domain names such as "laxative.com" or "heartburn.com" may be irresistible to some.

MTV Networks v. Curry, 867 F. Supp. 202 (S.D.N.Y. 1994). MTV sued one of its former employees, Adam Curry, for trademark infringement based on his use of the Internet domain name "mtv.com." Curry had developed the web site for MTV while an employee there but registered the domain name under his own name. Curry wanted to take the domain name with him following his dismissal.

lbid. at 203, n.2.

See, e.g., Multi-Local Media Corp. v. 800 Yellow Book, 813 F. Supp. 199 at 205 (E.D.N.Y. 1993), finding a likelihood of confusion between the defendant's 1-888-YELLOW BOOK phone number and the plaintiff's "YELLOW BOOK" trademark. See also American Airlines v. 1-800-A-M-E-R-I$C-A-N$ Corp., 622 F. Supp. 673 (N.D. III. 1985). I know of no reported trademark cases in Canada concerning the status of telephone mnemonics.

$3 \quad$ Pizza Pizza v. Canada (Registrar of Trademarks), [1989] 3 F.C. 379 (C.A.).

32726 F. Supp. 1195 (D. Minn. 1989).

$3 \quad$ See supra note 21 and surrounding text. 
There exists a distinct split in authority on the matter of generic terms in telephone mnemonics. In Dial-A-Mattress Franchise Corp. v. Page, ${ }^{34}$ the plaintiff had acquired the telephone number in a local area code corresponding to the mnemonic "MATTRES." The defendant obtained the 1-800 number with the same mnemonic and advertised the number in the same local area. Dial-A-Mattress filed a trademark infringement action, and the trial court issued a preliminary injunction enjoining the defendant's use of the plaintiff's mnemonic based upon likelihood of confusion.

Upon reviewing the case, the appellate court clearly stated that Dial-A-Mattress could not claim trademark rights to the generic word "mattress" if the word was used merely to identify the product. The court did find, however, that companies frequently promote their telephone numbers as key identifiers of their business. There is the possibility that customers may dial the defendant's 1-800 number thinking that it was the plaintiff's new toll-free number and inadvertently reach the defendant's business. The appellate court ruled that companies in this situation should be able to remain free from having their telephone number confused with a deceptively similar one, even though the mnemonic happens to spell out a generic term. Thus, the trial court's preliminary injunction was upheld.

Dranoff-Perlstein Associates v. Sklar represents the opposing legal opinion to DialA-Mattress. ${ }^{35}$ Though the court agreed with Dial-A-Mattress that telephone mnemonics can function as trademarks, it asserted that, as such, they are subject to the same principles as traditional trademarks and, hence cannot be protected if generic. There is an inter-circuit conflict between Dranoff-Perlstein and Dial-A-Mattress, so neither opinion prevails as settled law. Dranoff-Perlstein would be the better of the two to apply to domain name trademark issues, since the reasoning in Dial-A-Mattress would allow the domain name holder of "books.com" to preclude registration of "book.com" and other variants. ${ }^{36}$

In addition to the caselaw applicable to 1-800 numbers containing generic terms, there is a further body of law concerning parasitic telephone numbers, which may be of use in predicting how courts will decide parasitic domain names. In Holiday Inns v. 800 Reservations, the appellate court reversed the trial court's finding of trademark infringement. ${ }^{37}$ Holiday Inns possessed the 1-800 mnemonic "HOLIDAY." A travel reservation agency, which booked reservations in numerous hotels including Holiday Inns, obtained the telephone number 1-800-405-4329 which happened to correspond to the mnemonic "HOLIDAY," with the numeral zero in the place of the letter "O." 800 Reservations counted on consumers making the mistake of not pressing the number six on the telephone keypad, which corresponds to the letter " $O$ " in the telephone cipher, but pressing zero instead because of its visual resemblance to the letter. This use of a similar telephone number is analogous to the parasitic uses of domain names described

14 880 F.2d 675 (2d Cir. 1989) [hereinafter Dial-A-Mattress].

3 Dranoff-Perlstein Associales v. Sklar, 967 F.2d 852 (3d Cir. 1992) [hereinafter Dranoff-Perlstein].

36 The Dial-A-Mattress decision is criticized by Nathenson, supra note 3.

17 Holiday Inns v. 800 Reservations, 86 F.3d 619 (6th Cir. 1996). 
above. The appellate court reasoned that the confusion pre-existed in the minds of the consumer and was not a creation of the defendant. ${ }^{38}$

The Holiday Inns case appears on the facts to be most similar to cases such as "micros0ft.com." However, the cases are quite different: no one makes the mistake of typing " 0 " instead of " 0 " on a computer keyboard. On the other hand, the precedent set by Holiday Inns may be useful in deciding cases where the SLD name is identical, but the TLD name is different. In these situations, the confusion exists beforehand in the mind of the Internet user. The fact that a user accesses the wrong web page is simply a matter of dumb luck, and usually a few more guesses gets it right. No action lies with these kinds of mistakes and confusions. ${ }^{39}$

The existing telephone mnemonic caselaw is sufficient authority to establish that Internet domain names may function as trademarks. However, with the current split in authority, one area of uncertainty is how much protection to give domain names that incorporate generic terms. In order for trademark rights to vest in the domain name, the domain name holder must use the name to identify the source of goods or services, but it is unclear what types of online goods or services are sufficient to secure trademark rights.

\section{NSI Domain Name Dispute Policy}

Perhaps mindful of the impending legal storm, the NSI established a dispute process separate from the regular court system by allowing third parties to challenge the registration of a domain name. ${ }^{40}$ Those who challenge the registration of a domain name must first notify the domain name holder that the domain name registration violates the challenger's legal rights. After notifying the domain name holder, the challenger must submit to NSI a copy of the notice along with a certified copy of a foreign or federal trademark registration identical to the second-level of the domain name. Whether the domain name holder could continue using the disputed domain name depended on which of two dates was the earlier - the date of activation of the domain name or the effective date of registration of the challenger's trademark. NSI would compare the two dates. If the use of the domain name predates the effective date of registration, the domain name holder would be allowed continued use of the domain name, unless the NSI received a court order to the contrary. If the activation date of the domain name is after the effective date of the registration, NSI would give the domain

The same fact situation, and the same ruling, exists in U-Haul Int'l v. Kresch, 943 F. Supp. 802 (E.D. Mich. 1996).

A disclaimer prominently displayed on a web page with an address commonly confused with that of another, claiming no affiliation or connection, may go a long way to allaying "pre-web site confusion." Courts will look kindly on such efforts, such as in Bensusan Restaurant v. King, 937 F. Supp. 295 at 301 (S.D.N.Y. 1996). On the other hand, if there are no efforts to clear up any confusion, and it is clear that the intention is to deceive, a court may have enough reason to conclude that the confusion was the creation of the second user of the mark. See Planned Parenthood Federation of America v. Bucci. DC SNY, No. 97 Civ. 0629.

41 The dispute policy went into effect in November 1995. The policy has undergone four revisions since then. The current policy is available at http://www.netsol.com/rs/dispute-policyb.html. 
name holder thirty days in which to supply proof of a foreign or federal trademark registration. ${ }^{41}$ Failing that, the domain name would be placed "on hold" after a ninety day period. Once the domain name is placed on hold, the name is unavailable for use by anyone, including the challenging trademark owner. NSI would keep the domain on hold until the dispute is settled either through negotiation or litigation.

NSI justifies its domain name trademark policy on the grounds that the registration authority is stuck between the polarized demands of trademark holders and domain name holders. NSI considers itself to be merely a registrar of Internet addresses and not the adjudicator of trademark disputes. NSI prefers that disputes be worked out between the parties involved, through the proper legal authorities, and does not itself want to become directly involved. The irony is that neither of these two objectives - avoiding the role of adjudicator and avoiding being embroiled in litigation - were brought about by the domain name dispute policy.

The dispute policy gives NSI de facto judicial power of granting injunctions without any of the standards applied by the courts. For instance, NSI does not give any consideration to the balance of convenience. In some cases, putting the domain name on hold would mean that the domain name holder would go out of business. Take for example, the dispute over "juno.com." Juno Electric, a maker of light fixtures, initiated a challenge against Juno Online, a provider of e-mail services. Having the domain name put on hold would mean that the 700,000 subscribers to Juno Online would lose their e-mail addresses. ${ }^{42}$ The resulting disruption of e-mail services would probably have convinced disgruntled customers to find their e-mail services elsewhere, putting Juno Online out of business.

The fundamental flaw with the NSI policy is that it ignores common law rights in trademarks. Mere evidence of common law rights would not suffice as a defense against a third-party challenge to a domain name registration. Inequitable situations can arise when a party with superior trademark rights, based on seniority of use, is forced to relinquish the domain to the junior trademark user who had the foresight to register the mark. ${ }^{43}$ The NSI policy makes a federally registered trademark a necessity for doing business online since it is a best means of defense against a third-party challenge.

For the trademark owner who is merely covetous of a domain name, the dispute policy is not completely satisfactory in that NSI does not transfer the domain name to

NSI's notice became known as a "thirty-day letter." In earlier versions of the Dispute Policy, the holder of the challenged domain name could beat the thirty day letter by registering the disputed domain name as a trademark in Tunisia - the only country in the world that could process the application so quickly. Later revisions of the Dispute Policy closed this loophole by requiring that the registration date of the domain name holder's trademark pre-date the commencement of the challenge.

42 C. Oppedahl, "Remedies in Domain Name Lawsuits: How Is a Domain Name Like a Cow?" (1997) 15 J. Marshall J. Computer \& Info. L. at 437.

4 S.M. Abel \& C.L. Ellerbach, "Trademark Issues in Cyberspace: The Brave New Frontier" Available at http://www.fenwick.com/pub/trademark_issues_in_cyberspace.html (last revised 21 July 1998). 
the trademark owner. Nonetheless, the dispute policy promotes that goal because in some cases, getting a domain name placed on hold will cause the domain name owner to go out of business, because their limited financial resources preclude them from taking on litigation with the challenger or NSI. This leaves the domain name once again available for the challenger to claim for their own. However, in the usual case, if the trademark owner wants ultimately to secure the right to use the domain name, the trademark owner must settle the dispute either by negotiating a settlement with the domain name holder or by litigating the dispute.

\section{Litigation}

Unlike the NSI dispute resolution policy, courts use the traditional confusion analysis. A finding of likelihood of confusion is predicated upon similarity of marks and competition between the two parties in the same market. To carry out a traditional confusion analysis on the Internet, the court must have tests for two issues: when is one mark similar to another, and when do two markets overlap? Assuming similarity of marks, there remain two horns of the dilemma - either the markets overlap or they do not. Squatters avoid the horns: by definition, they are not competitors in the same market; they are only competitors for the domain name. As we shall see below, courts are forced to create novel solutions to deal with cyber-squatters.

The first reported case in which a court made the standard "likelihood of confusion" ruling in a domain name dispute is Comp Examiner Agency v. Juris. ${ }^{44}$ The case involved one company using a direct competitor's trademark in a domain name with respect to the same goods and services. Juris was the owner of a federal trademark registration for "JURIS" in connection with goods and services marketed to lawyers. Comp Examiner Agency had registered and used the domain name "juris.com" in connection with a Web site offering products to lawyers. In a paradigm ruling of "passing off," the court enjoined the defendant from using "Juris" or any confusing variant. The defendant was, however, granted three months to continue using the domain name and web site to post a referral notice to the defendant's new site. The Juris case stands for the proposition that the use of a mark in a domain name in connection with directly competing goods will be trademark infringement under the "likelihood of confusion" test.

\section{A. Dilution}

In 1995, U.S. federal trademark legislation - the Lanham Act - was amended by the Federal Trademark Dilution Act. ${ }^{45}$ The Dilution Act added a new s. 43(c) to the Lanham Act to provide protection to "famous" marks against uses that dilute the distinctiveness of the mark. To have a cause of action under that provision, a party must show that its mark is famous and that the defendant's use of the mark is a commercial use "in commerce" and is likely to cause dilution. The statute defines

41996 WL 376600 (C.D. Cal. 22 May 1996).

4s Federal Trademark Dilution Act of 1995, Pub. L. No. 104-98, 109 Stat. 985, 986 (1996) (codified at 15 U.S.C. $\$ 1125(c), 1127$ ) [hereinafter Dilution Act]. 
"dilution" to mean "the lessening of the capacity of a famous mark to identify and distinguish goods or services." ${ }^{46}$ It is noteworthy that the statute does not attempt to define "famous," nor does it require a showing of competition or likely confusion. The intent of s. 43(c) of the Lanham Act is to protect marks such as DuPont, Buick, or Kodak to such an extent that their use in any other context apart from that for which they are most well-known could be enjoined.

The new anti-dilution provision in the Lanham Act became the chief instrument to be used in the fight against cyber-squatters. Indeed, the legislative history of the Dilution Act strongly suggests that this was one of the principle aims of the amendment to the Lanham Act. Speaking in favour of the legislation, Senator Patrick Leahy (D-Vt.) expressed his "hope that this antidilution statute can help stem the use of deceptive Internet addresses taken by those who are choosing marks that are associated with the products and reputations of others."47 There are two leading cases establishing the dilution cause of action against cyber-squatters. Coincidentally, the two cases have the same defendant: Intermatic Inc. v. Toeppen ${ }^{48}$ and Panavision Int'l L.P. v. Toeppen. ${ }^{49}$ The fact situation is very nearly identical in each, as is the reasoning employed in the judgment; I will therefore discuss only Panavision. ${ }^{50}$

Plaintiff Panavision International L.P. makes and sells cameras and photographic equipment for the movie and television industry and owns the federally registered trademarks "Panavision" and "Panaflex" in that business. Defendant Dennis Toeppen obtained from NSI a registration for the domain "panavision.com." Toeppen's web site at "panavision.com" simply displayed aerial views of Pana, Illinois. When Panavision attempted to establish its own Internet presence, it discovered that Toeppen was squatting on "their" domain. Panavision refused Toeppen's demand of $\$ 13,000$ to discontinue his use. Toeppen then registered Panavision's "Panaflex" trademark as the domain name "panaflex.com" and displayed only the word "hello" at the web site. Panavision sued Toeppen for trademark dilution, trademark infringement, and unfair competition.

The court found Panavision's marks to be "famous" and, so, worthy of protection from dilution. The court next concluded that Toeppen made a commercial use of the Panavision marks. Toeppen's "business" is arbitrage - to register trademarks as domain names and then to sell the domain names to the trademarks' owners. In making its finding of dilution, the court stated that "Toeppen was able ... to eliminate the capacity of the Panavision marks to identify and distinguish Panavision's goods and services on the Internet." 51

15 U.S.C. $\$ 1127$.

United States Senate, 29 December 1995, Cong. Rec. S. 19312 (104th Cong. 1995).

Intermatic v. Toeppen, 40 U.S.P.Q.2d (BNA) 1412 (N.D. Ill. 1996) [hereinafter Intermatic].

Panavision Int'l L.P. v. Toeppen, 945 F. Supp. 1296 (C.D. Cal. 1996) [hereinafter Panavision]. Intermatic preceded Panavision, but, interestingly, did not rely upon it.

Panavision, supra note 49 at 1304. 
The reasoning in this case is controversial for two reasons. First, the court had to stretch the meaning of "use in commerce"; Toeppen's web page was not connected with the sale of any goods or services. Second, in holding that the actions of the defendant "eliminated" Panavision's ability to exploit its marks, the court ignored the possibility that Panavision could register any number of domains incorporating the Panavision marks, such as "panavisioncameras.com." 52

Section 43(c) of the Lanham Act has been successfully applied by plaintiffs in several other domain name disputes. In TOYS " $R$ " US v. Akkaoui, the court found the "Us" category of marks to be famous and distinctive marks eligible for protection under s. 43(c). ${ }^{53}$ The court granted an injunction against the use of "adultsrus.com," an "adult" web site peddling sexual paraphernalia. In Hasbro v. Internet Entertainment Group, the court granted Hasbro's motion for an injunction of the use of "candyland.com" which was also a sexually explicit web site. ${ }^{54}$ Critics have pointed out that these two cases over-extend the meaning of "famous," and that the courts probably let the sexually explicit nature of the web sites in question influence their judgments. ${ }^{55}$

\section{B. Canadian litigation}

PEINET v. O'Brien was the first Canadian case to consider an action of passing off in connection with a domain name. ${ }^{56}$ The plaintiff, an Internet service provider, had acquired the domain name "peinet.pe.ca" through CA Net, the Canadian Internet authority. The defendant, O'Brien, who was a former employee of PEINET, started up his own business as an Internet provider, Island Services Network, to compete with PEINET. O'Brien registered the domain name "pei.net" with InterNIC.

The defendant persuaded the court that his domain name would not be confused with the substantially identical name of the plaintiff, PEINET. Although both parties competed in providing Internet services, the court dismissed the application for an interlocutory injunction on the basis that there would be no likelihood of confusion. The court found that the plaintiff failed to show it had established its reputation. The court was also influenced by the fact that the defendant had agreed to stop using the domain name "pei.net" and register "isn.net" instead.

This case is poorly decided because it turned in large part on the use of upper rather than lower case lettering. The court failed to appreciate that Internet domain names are not case sensitive; as such, there is a likelihood that a reasonable person would be

Oppedahl, supra note 42 at 455 . Oppedahl argues that Panavision and its twin, Intermatic, are controversial in a third respect - they order the transfer of the domain name when s. 43(c) of the Lanham Act specifies only cease and desist relief.

s) TOYS "R" US v. Akkaoui, 40 U.S.P.Q.2d (BNA) 1836 (D.C. Cal. 1996).

s4 Hasbro v. Internet Entertainment Group, 40 U.S.P.Q.2d (BNA) 1479 (D.C. Wash. 1996).

ss M.B. Landau, "Problems Arising Out of The Use of "www.trademark.com": The Application of Principles of Trademark Law to Internet Domain Name Disputes" (1997) 13 Ga. St. U. L. Rev. 455 at 495.

so PEINET v. O'Brien (1995), 61 C.P.R. (3d) 334 (P.E.I.S.C.T.D.). 
confused about the connection between the domain name in question and the identity of the company providing the services.

A recent and ongoing Canadian case, ITV Technologies v. WIC Television, is a dispute over the SLD "itv." The defendant in this case is a well-established television broadcasting concern, operating nine television stations across Western Canada. One of these stations is CITV in Edmonton which has been broadcasting under the name "ITV" since 1974. WIC is the registered owner of two ITV trademarks, used in association with audio and video wares and the service of broadcasting of those wares. WIC had also registered the domain name "itv.ca" and was using the address for an ITV station web site. This web site provides information on the station's programming, and has a live feed from the station's on-air broadcast.

The plaintiff, ITV Technologies ("Technologies"), had been involved in Internetrelated services since November 1995. One of Technologies' Internet activities involves delivering video content online. This so-called "net-casting" is analogous to conventional broadcasting; however, it uses the Internet, rather than the airwaves, as the medium of transmission. Technologies obtained the domain name "itv.net" and used this Internet address and the business name "ITV.Net" to identify its services. ${ }^{58}$

After learning about the existence of the "itv.net" web site in January 1997, WIC contacted ITV Technologies demanding that they cease and desist. Technologies responded by seeking an order from the court to expunge the ITV trademark. Failing that, Technologies sought a declaratory judgment from the court to the effect that the ITV trademark does not preclude the use of the domain name "itv.net." In its counterclaim, WIC alleged that the "itv.net" domain name violates the ITV trademark, and that Technologies was passing off its wares as those of WIC. On the matter of passing off, WIC claimed that Technologies had broadcast over the Internet a program originally produced by WIC; this particular netcast displayed the ITV trademarks and had occurred without the authorization of WIC. WIC claimed that Technologies' actions had resulted in a loss of control over the wares bearing the ITV trademarks and, hence, a loss of control over the goodwill associated with those trademarks. WIC sought injunctive relief, enjoining the use by Technologies of the "itv.net" domain name.

This case is interesting for several reasons. First, it involves two companies that are in the same jurisdiction; ${ }^{59}$ moreover, the two are arguably in the same line of business, insofar as both are involved in video productions and their broadcasting over telecommunications networks; finally, the SLDs in the domain names held by the two companies are identical to each other and to one of the two registered trademarks. Oddly, in this case it is not the trademark owner that is the plaintiff; rather, it is the domain name holder. Moreover, there is some suggestion that Technologies may have squattor's motives. In his affidavit, the President of Technologies asserted that "if an

ITV Technologies v. WIC Television, [1997] F.C.J. No. 1645 [hereinafter ITV v. WIC]. The domain name "itv.com" has been registered to someone in London, England. At the moment, the address does not call up any web pages.

Both companies are incorporated in British Columbia and have offices in Vancouver. 
offer satisfactory to Technologies is made, Technologies would sell the itv.net web address to [WIC]. ... This motion is merely about money. I believe [WIC] is attempting to get for free what it would otherwise have to purchase in the marketplace."

Technologies challenged WIC's trademarks on the grounds that they were not distinctive, either at the time of filing the application for their registration or at the time of filing the motion. Technologies also claimed that WIC has abandoned the ITV trademarks with respect to some wares and services. ${ }^{61}$ At first, this strategy seems to be not a little perverse: WIC has had long-standing use of the trademarks in connection with its television broadcasts, and the registration of those trademarks have gone hitherto unchallenged. However successful the motion to expunge WIC's trademarks may ultimately turn out to be, the immediate consequence of challenging the trademarks' validity was to curtail WIC's access to an interlocutory injunction.

The motion for an interlocutory injunction was dismissed by the Federal Court. The applicable rule of law is that, where the validity of the trademark is contested, the mere infringement of a trademark does not by itself constitute irreparable harm. Though the court considered the case to raise serious issues, it found no evidence of irreparable harm being suffered by WIC. Citing Syntex v. Novopharm, the court maintained that the evidence of irreparable harm must be "clear and not speculative" before an interlocutory injunction will be granted. ${ }^{62}$ Where the validity of the proprietary right to the mark is at issue, it would beg the question to find at the interlocutory stage that the mere infringement of a trademark is sufficient for irreparable harm. Such a finding would beg the question because it is the very proprietary right to the mark that is at issue. Consequently, Technologies has succeeded in avoiding an interlocutory injunction by the clever strategy of contesting the validity of WIC's ITV trademarks.

This case has yet to go to trial and so has not been decided on its merits. The case will probably hinge upon whether the business undertakings of the two parties are sufficiently similar for the two to be considered competitors. If the parties are deemed to be in sufficiently different lines of business, we would have in the off-line world a case of concurrent users. The problem of concurrent users on the Internet has not been resolved, with Fry's Electronics yet to go to trial, and similarly with ITV.

\section{U.K. Litigation}

Although domain name disputes, particularly those involving the "com" TLD, often involve American interests, there is a growing number of cases that involve parties and courts in different countries. In the dispute between Prince PLC and Prince Sports Group, the court in the U.K. was called upon to decide a trademark case that crossed jurisdictional boundaries. 
The Prince case revolves around the "prince.com" domain which Prince PLC, a British computer services company, obtained in February 1995 from NSI. Prince PLC also obtained the domain "prince.co.uk." When Prince Sports Group, Inc., an American manufacturer of sporting goods which has several trademark registrations for PRINCE in both the U.S. and the U.K., tried to register the "prince.com" domain, it was informed by NSI that the name was not available. Although Prince Sports Group registered several other domain names, including "princetennis.com" and "princesportsgroup.com," the company was nonetheless intent on wresting "prince.com" from Prince PLC.

To trigger NSI's dispute policy, Prince Sports Group sent a demand letter to Prince PLC in the U.K. The letter threatened litigation if the British company did not assign the "prince.com" domain to Prince Sports Group and further agree not to use "prince" in any new domain name Prince PLC may subsequently select. Prince PLC does not own a trademark registration for its PRINCE service mark in the U.K. or elsewhere.

Prince Sports Group then initiated a domain name dispute with NSI. Under the provisions of NSI's dispute policy, Prince PLC was given 30 days to relinquish the "prince.com" domain, to produce a valid pre-existing trademark registration, or to file legal action. Were Prince PLC to do nothing, the NSI would put its domain on hold.

Before the domain went on hold, Prince PLC filed a civil action against Prince Sports Group in the High Court in London pursuant to s. 21 of the Trade Marks Act, 1994, (U.K.). ${ }^{63}$ Prince PLC sought declarations from the U.K. court that its registration of the "prince.com" domain did not infringe Prince Sports Group's trademark rights, and that Prince Sports Group's allegation of infringement and threats of legal action were unjustified. Moreover, Prince PLC sought to enjoin Prince Sports Group from threatening legal action for Prince PLC's use of the "prince.com" domain. Although Prince PLC had not satisfied the requirements of NSI's dispute policy, NSI did not put the "prince.com" domain on hold: instead it waited for the disposition of the U.K. court on the matter. ${ }^{64}$

In July 1997, the U.K. court ruled that Prince Sports Group's threats were unjustified. Although it issued an injunction enjoining the U.S. company from repeating its threats, the U.K. court refused to declare that Prince PLC's use of the "prince.com" domain name was not an infringement of Prince Sports Group's U.K. registered trademarks. The U.K. court declined to be involved in the legal battle over domain name ownership because it might interfere with the outcome of the American lawsuit filed by Prince Sports Group. Prince PLC was thus left in control of the "prince.com" domain. Subsequently the case settled: Prince Sports Group dropped its U.S. lawsuit and allowed Prince PLC to retain ownership of the "prince.com" domain.

6.3 Prince PLC v. Prince Sports Group, CH1997 - P2355, filed 30 July 1997.

in While the British case was pending, Prince Sports Group sued both NSI and Prince PLC in a U.S. federal court. See Prince Sports Group v. Prince PLC, (D.N.J. filed 3 July 1997), No. $97 \mathrm{cv03581.}$ 


\section{Proposed Solutions}

There are a number of proposals to make changes to the overall landscape of the Domain Name System. The intent is to combat the conception that "com" is the only commercially viable TLD. In part, this misconception has been responsible for much of the present controversy. This section will canvas the major proposals and point out a system for domain name allocation already in place which could serve as a model for the rest of the Internet.

\section{A. GTLD-MOU}

In February 1997, the Internet Society (ISOC) struck an eleven-member International Ad Hoc Committee (IAHC). ${ }^{\text {is }}$ The committee was formed at the request of the Internet Assigned Numbers Authority (IANA), to examine the current Domain Name System and to propose improvements. Trademark issues were a chief concern of the IAHC, which included representatives from the World Intellectual Property Organization (WIPO) and the International Trademark Association (INTA). The IAHC Final Report culminated in the gTLD Memorandum of Understanding (gTLD-MoU), signed on 1 May 1997 by the ISOC, the IANA, and many other organizations involved in maintaining the Internet infrastructure and providing Internet services.

To reduce the perceived pressure on the existing gTLDs, particularly the "com" domain, the IAHC proposed that the number of gTLDs be roughly doubled by adding seven new TLDs:

firm for businesses, or firms

store for businesses offering goods to purchase

web for entities emphasizing activities related to the World Wide Web

arts for entities emphasizing cultural and entertainment activities

rec for entities emphasizing recreation/entertainment activities

info for entities providing information services

nom for those wishing individual or personal nomenclature, i.e., a personal nom de plume. ${ }^{66}$

The chief motivation driving the IAHC recommendation is desire to reduce monopolistic control, both over SLDs and over the DNS as a whole. Increasing the choices for gTLDs creates more opportunities for a company to secure an SLD with its preferred mnemonic string. ${ }^{67}$ Thus, there is a greater chance that a trademark holder will be able to obtain a domain name that closely matches their trade name or mark. If a company were to find its preferred domain name already taken in one gTLD, there body for the Internet which is otherwise controlled by no one particular interest. The IAHC web site is at http://www.iahc.org.

(s) Final Report of the International Ad Hoc Committee: Recommendations for Administration and Management of gTLDs, online <http://www.iahc.org/draft-iahc-recommend-00.html >) (4 February 1997) at s. 8.1.1 [hereinafter IAHC Final Report]. 
would still be the opportunity to apply for the domain name under a different gTLD. No one company could be in the position of being the exclusive user of a particular mark in a commercial TLD, since there would be more than one gTLD carrying the implication of commercial activity. The new gTLDs would weaken the power of squatters, since they could not hold a valuable domain name hostage with just one registration. The division of the proposed new gTLDs into broad, descriptive categories could even stave off domain name disputes before they happen. The hope is that domain name applicants would steer themselves toward the appropriate category. For instance, those who want to register a vanity domain incorporating their own proper names would do so under the "nom" domain. This might avoid potential conflicts between a man named Howard Johnson and the hotel chain. ${ }^{68}$

In addition to making it more difficult to gain a monopoly over a particular SLD name, the IAHC proposal is also designed to eliminate monopolistic practices at the level of the administration of the gTLDs. Currently, the NSI exercises exclusive control over the existing gTLDs. As part of the IAHC proposal, administration of the new gTLDs would be shared by up to twenty-eight registrars. In its Final Draft, the IAHC wrote:

[The] creation of such additional gTLDs would allow a form of natural competition with existing gTLDs, creating alternate entry points for access to the gTLD domain space[.] ...[S]uch natural forms of competition will assist in preventing the operators of any particular gTLD from assuming the role of a monopoly provider with the associated inherent risks of monopoly-based market trading practices. $^{.9}$

What is most concerning to the IAHC about the current gTLD registration monopoly, is the role of the NSI as arbiter of trademark disputes. The NSI's established dispute procedure in effect gives the NSI the power to grant injunctions against domain name holders, without a proper legal analysis of the strength of the trademark owner's claim. The IAHC envisions a dispute resolution procedure that minimizes the involvement of the registrar and avoids costly litigation where possible. At the same time, the IAHC recognizes the essential role of the courts, where the merits of trademark actions can be properly assessed. A novel feature advocated by the IAHC proposal is the use of online mediation and arbitration. These measures will be administered by the World Intellectual Property Organization Arbitration and Mediation Center in Geneva. The IAHC calls for several changes to existing registration and dispute procedures. For example, the IHAC recommended a sixty day waiting period for an application for a domain name, during which time the applied-for domain name would be published in a list of pending domain names. Third parties could search the list and oppose any domain name before it becomes activated. In another recommended change to existing procedures, a domain name will not be suspended prior to the conclusion of the challenge proceedings unless the challenge is filed within thirty days of the date of 
registration of the domain name. This results in a situation very different from the "reverse hijacking" situation.

The IAHC proposal to expand the top-level domain space is not without its problems. First, owners of famous names can be expected to register their name under each of the new gTLDs to preempt squatters. Although expanding the TLDs has the worthy goal of discouraging monopolies, it also increases the space that companies must police for potential dilution of their marks. There is, for example, increased opportunity for the parasitic domain names and confusion between the same SLD across two different TLDs. Second, each of the new gTLDs is sufficiently broad that they overlap. Companies with a diverse range of goods and services would have reason to register its name under every new gTLD except "nom." Finally, the new gTLDs that are so similar can increase the likelihood of confusion on the part of the consumer. On the matter of establishing online mediation and arbitration, such efforts at dispute resolution require a globally recognized body of law applicable to domain names and trademarks. However, no such body of law is exists. ${ }^{70}$

\section{B. NSI'S PROPOSAL}

A rival to the IAHC proposal is that put forward by NSI. In its 29 April 1997 paper titled "Secure Internet Administration and Competition in Domain Naming Services," NSI suggested that "[t]here can be as many TLDs as there are second-level domains." The NSI paper proposes that the creation of new TLDs, and the registration of SLD names within those TLDs, be left up to open competition in the marketplace. With no limit to the number of TLDs, squatters would have a difficult time cornering the market on a particularly desirable mnemonic.

The NSI proposal for changes to the topography of the domain name system shares all of the defects of the IAHC proposal without solving any additional problems. The proposed system would dramatically increase consumer confusion and would make it much more difficult for trademark owners to police the top-level domains for possible trademark infringement and dilution.

\section{The Geographical Solution}

The difficulties over trademarks and domain names in part stem from the fact that the "com" domain hierarchy is too generic and homogenous; it lacks any context with which to differentiate between goods and services. All businesses become virtual neighbours, competing in only one line of business - online services. Domain names are unique and global, but trademarks are multiple and enforced on a territorial basis. One proposal for making the Internet more "trademark friendly" would be to require domain names to reflect geographical location, by adhering to the country-code TLDs, and where applicable, the further subdivision of those country domains into regions and

70 The IAHC recognizes this as an fundamental problem, yet offers to solutions. See $I A H C$ Final Report, supra note 66 at s. 7.2.1.

7 Online: <http://www.netsol.com/papers/internet.html> (last modified: 6 June 1998). 
territories. In effect, the proposal is to get rid of "com" and other gTLDs and limit registration of domain names to country-code TLDs. ${ }^{72}$ The generic domain hierarchies could be maintained but would appear only within a country-code TLD, as is currently the practice in Commonwealth and other countries. ${ }^{73}$ The "us" domain should be used instead of the current practice of using "com" as an ersatz country-code TLD for the U.S. ${ }^{74}$

One may object to this proposal on the grounds that it displaces the problem by one remove but does not solve it. Even if all domain names in the United States were to use the "us" TLD, that would in no way reduce the potential for disputes over a domain name such as "mcdonalds.com.us." This objection is fundamentally correct: without further measures and precautions, a simple reorganization of the domain name system will not be enough to resolve trademark issues. The example set by registration procedures in Canada for the "ca" domain provides a good indication of what further steps are necessary.

\section{The Canadian Model}

The "ca" domain is structured according to Canadian political geography, yielding domain names that follow the patterns: "xyz.prov.ca," or "xyz.town.prov.ca." 75 To qualify for a second level domain directly under the "ca" domain, "xyz.ca," the organization must be federally incorporated, or have registered a trademark with the Canadian Registrar of Trademarks. There are strict rules for generating an SLD string out of the name of the organization or the trademark: the trademark must be used in full, though prepositions and other extraneous words in the name of the organization may be removed, and common abbreviations are allowed. The Canadian model virtually removes all possibility of squatting, since only trademark owners may register "theirtrademark.ca." Concurrent users in different regions of the country may share the same third or fourth-level string. While this does not completely remove the possibility of disputes over domain names, it makes them much less likely.

The chief objection to the geographical solution is that it ignores the fact that one of the most important features of the Internet is its ability to transcend geographical boundaries. Internet users typically do not know, and are are not expected to know, the geographical location of sites with which they connect. Imposing geographical structure on the domain name system will decrease guessability. A related objection points out that, with increasing numbers of companies catering to the emerging online markets, many will want to avoid domain names that carry implications of having limited,

$72 \quad$ This proposal is championed by Barger, supra note 24.

73 $\quad$ lbid. at $\S$ I.A.

7s Though I consider this proposal to be the strongest, it does not appear as if there is much support for it: "There are no current plans of putting all of the organizational domains EDU, GOV, COM, etc., under US. These name tokens are not used in the US Domain to avoid confusion." $A$. Cooper \& J. Postel, "The US Domain, Request for Comments: 1480" online: <ftp://rs.internic.net/rfc/ rfcl480.txt> (June 1993), .

75 The application for a domain name in the "ca" domain is available at flp://ftp.cdnnet.ca/cadomain/application-form. 
regional scope. The disadvantage to the Canadian model is that common law users of trademarks must settle for what is perceived to be less desirable, geographically tied domain names.

The first objection can be met with new developments in Internet technology. Socalled "search engines" are powerful computers whose function is to carry out keyword searches on the entire Internet. There are a dozen or more popular search engines which are used free of charge by hundreds of thousands of Internet users each day. ${ }^{76}$ As a test case, I tried to find the web page of Harvest House, makers of reproduction Arts and Crafts furniture in Richmond Hill, Ontario. I had prior knowledge that the address of their web page is "www.harvesthouse.on.ca." Using Lycos, I found the correct web page in seconds.

\section{Classification of Goods and Services}

What is missing from the geographical solution is the ability to distinguish between different classes of goods or services. A further proposal advocates including a description of the goods or services offered by the domain name holder into the domain name. ${ }^{77}$ The description could appear on its own as a second-level domain, as in "abc.travel.com," or could be concatenated with the mark or name of the company using the hyphen, as in "abc-travel.com." What is attractive about this proposal is the way in which it reflects the context-specificity of trademarks. Owning a trademark gives one rights only with respect to a limited class of goods or services and does not preclude another from using the same mark for a different class of goods or services. The proposal to tie domain names with descriptions of goods or services is a means of allowing concurrent uses of the same mark to exist in the domain name system. For instance, it would make it possible for "abc-travel.com" and "abc-computers.com" to co-exist peacefully. As with the other proposals, what suffers is guessability. As Andre Brunel and May Liang put it:

Is it "disney-film.com," "disney-films.com," "disney-movie.com," "disney-animation.com," "disneyamusementpark.com," "disney-themepark.com," "disney-mickey.com," etc.?"

To avoid this issue, the descriptions could be based on a standardized schema, such as the International Schedule of Classes of Goods and Services established by WIPO. This Schedule classifies thirty-four different types of goods and eight different types of services. $^{79}$ The problem them becomes expecting the Internet public to become educated on these standardized categories.

76 Popular search engines are Altavista, Infoseek, Lycos, WebCrawler, and Yahoo.

$n \quad$ An articulation of this proposal can be found in J.W. Morando \& C.H. Nadan, "Can Trademark Law Regulate The Race to Claim Internet Domain Names?" (1996) 13:2 Computer Law 10 at 10. A. Brunel \& M. Liang, "Trademark Troubles With Internet Domain Names and On-line Screen Names: Roadrunning Right Into the Frying Pan" (1996) 8:9 J. Proprietary Rts. 2 at 7.

77) The classes of goods and services are detailed in M.B. Landau, "Problems Arising Out of The Use of www.trademark.com: The Application of Principles of Trademark Law to Internet Domain Name Disputes" (1997) 13 Ga. St. U. L. Rev. 455 at n. 66. 


\section{CONCLUSION}

The current trademark controversy over Internet domain names was brought on by a number of failures on the part of NSI. NSI was slow to appreciate the trademark significance of domain names. It was adamant in its denial that domain names have any trademark status, despite exhortations to the contrary on the part of INTA and other bodies of experts. ${ }^{80}$ The NSI was clumsy in its policy making and, perhaps even more importantly, lax in the policing of those policies. NSI should have been more diligent in enforcing its policies including the "one domain per organization" rule. Certainly, Dennis Toeppen and other cyber-squatters have no right to register hundreds of domain names. The $\$ 100$ fee per registration that the NSI started to impose beginning in August 1995 was supposed to check idle speculation. The fee did little to deter determined speculators. As the rate of registration began to climb exponentially, quickly reaching levels of tens of thousands registrations per month, NSI suddenly found itself with the goose that lays golden eggs. They had no incentive to set strict controls on domain name registration.

NSI should have enforced a policy limiting use of the "com" top-level-domain to only bona fide commercial parties. Domain names such as "mcdonalds.com" or "deltaairlines.com" should never have been registered to an individual with no proof of rights to those marks. Parties registering domain names under the "com" domain should be required to submit proof, as is the case in the "ca" domain, of a trademark or proof of doing business under the name applied for. Either the NSI or applicants should be required to conduct trademark searches. The NSI begged off any responsibility for attending to trademark issues. In an interview with journalist Joshua Quittner in the fall of 1994, Scott Williamson, a manager at NSI, claimed that limited resources were the reason why the InterNIC does not check for trademark violations: "If we had to research every request for a domain name right now, I'd need a staff of 20 people.... Trademark problems are the responsibility of the requester." ${ }^{81}$ This excuse rings hollow when one considers that NSI was collecting a $\$ 100$ fee from over a half a million domain names it has registered and is on a $\$ 5.9$ million five-year contract from the U.S. Government. The current contract between the NSF and NSI expires in September 1998. Hopefully the new registrar will incorporate some of the suggestions of the IHAC and will impose stricter regulation and control of domain name and trademark disputes.

"In September 1995, the INTA Board of Directors approved a resolution that provided that domain names can function as trademarks and that the assignment and use of domain names can result in infringement of trademark rights. The InterNIC, however, continued its previous stance and refused to follow the INTA's admonition that it must "come to grips with legal issues."' Deuker, supra note 13 at 500 .

"II Juittner, "Billions Registered: Right Now, There Are No Rules to Keep You From Owning a Bitchin' Corporate Name As Your Own Internet Address" (1994) Wired at 54 online: wired $<w w w . w i r e d . c o m>$. Incidentally, Quittner touched off an imbroglio when he registered "mcdonalds.com" under his own name. 